\title{
OXFORD JOURNALS
}

OXFORD UNIVERSITY PRESS

Some Theoretical Aspects of Agricultural Policies

Author(s): Joseph E. Stiglitz

Source: The World Bank Research Observer, Vol. 2, No. 1 (Jan., 1987), pp. 43-60

Published by: Oxford University Press

Stable URL: http://www.jstor.org/stable/3986573

Accessed: 29/04/2013 14:04

Your use of the JSTOR archive indicates your acceptance of the Terms \& Conditions of Use, available at

http://www.jstor.org/page/info/about/policies/terms.jsp

JSTOR is a not-for-profit service that helps scholars, researchers, and students discover, use, and build upon a wide range of content in a trusted digital archive. We use information technology and tools to increase productivity and facilitate new forms of scholarship. For more information about JSTOR, please contact support@ jstor.org. 


\title{
SOME THEORETICAL ASPECTS OF AGRICULTURAL POLICIES
}

\author{
Joseph E. Stiglitz
}

$\mathbf{I}$ n virtually every country, developed and developing alike, governments intervene in agricultural markets. They subsidize farmers (mostly in developed countries); they tax farmers (mostly in developing countries); ${ }^{1}$ they try to stabilize prices; they impose import tariffs and quotas; they restrict production; they provide food subsidies for urban areas; they support the use of fertilizer; they build irrigation systems; they offer extension services; they try to control marketing; and they provide credit, often below market rates. These programs have been at the center of growing controversy. They often impose huge financial burdens on the government and generate allocative inefficiencies in countries that are poor enough already. Yet governments in developing countries often seem to doubt the advice offered from the developed countries to abandon these policies, when the developed countries engage in not dissimilar practices themselves.

This article aims to provide a systematic framework within which to assess these various programs. ${ }^{2}$ The circumstances of individual countries differ so much that no single prescription would be appropriate for all. But the framework in this article should be useful for considering a wide range of cases.

A useful starting point is to ask, What are the legitimate reasons for government intervention in agricultural markets? In particular, what makes the market's own allocation either inefficient or otherwise "unacceptable"? There is a standard litany of such reasons; five are relevant to agriculture. ${ }^{3}$

1. Incomplete markets in insurance futures and credit. Farmers cannot get complete insurance against the big (output and price) risks they face. Rural credit markets, like agricultural insurance markets,

The Market and

Government Failures Approach 
are notoriously imperfect. Farmers' access to credit is limited, if they can obtain it at all. They often have to pay usurious interest rates, though this may have something to do with the likelihood of default. ${ }^{4}$

2. Public goods and increasing returns. These provide the justification for governments to finance water projects. In some cases, the marginal cost of using irrigated water, once the dam has been built, is relatively low, and the cost of monitoring water usage is relatively high. Water projects therefore satisfy both the criteria of pure public goods. The provision of water is almost always a natural monopoly, and a common (though not universal) response to such monopolies is production by government.

3. Imperfect information. Government supply of information can be thought of as a type of public good. (Where the government ascertains what crops grow best in a particular area, the information is best described as a local public good.) However, disseminating information is costly, and the benefits accrue mainly to those who receive it. So it is probably wrong to think of agricultural extension as a pure public service. It may be justified, however, by the next category of market failure.

4. Externalities. The successful adoption of a new technology by one farmer conveys valuable information to his neighbors and hence gives them a significant externality. The existence of this externality has been used to justify subsidies for farmers to adopt new technologies.

5. Income distribution. Perhaps the most important reason for government intervention in agriculture is concern with the distribution of income generated by free markets. Given the initial holdings of assets, this distribution need not, and often does not, satisfy society's ethical judgments. In particular, it may result in significant numbers of people having unacceptably low incomes or supplies of food. ${ }^{5}$ This suggests the government should design programs that increase the incomes of small farmers-and, for urban dwellers, a program of food subsidies. ${ }^{6}$

Though this list provides various rationales for government action, the link between them and actual government policies may be tenuous. Thus, measures aimed at reducing risk (like price stabilization programs) may actually increase the riskiness of farmers' income, and they often entail large subsidies. ${ }^{7}$ Though government policies may be defended in terms of helping the small farmer, the main beneficiaries may be large farmers. And though governments may claim that their policies redistribute income, the net impact of the programs may be regressive. $^{8}$

Critics of government programs thus claim that market failures are matched by a corresponding list of government failures (see Stiglitz 1986). The fact that markets face certain problems does not in itself justify government intervention; it only identifies the potential area for it. This caveat is particularly important in any assessment of public 
remedies for those market failures affected by imperfect information (for instance, imperfect credit markets), since the government is likely to face similar problems if it intervenes.'

To understand the nature of government interventions in agricultural markets, one must approach the problem from the perspective of the second best. Whether government or market failures are of greater importance may differ from country to country, and this will crucially affect the nature of the appropriate government policy. Failure to recognize this fact has given rise to much of the controversy over state intervention. Simplistic views-such as "governments should not intervene in free markets" - or even the more sophisticated view (based on optimal tax theory for developed countries) that "government should not impose trade taxes" become inappropriate once it is recognized that the government has limited instruments for collecting revenue (thus, some distortionary taxation is necessary) and for redistributing income (so that the surest way of improving the lot of the rural poor may be through trade taxes). ${ }^{10}$ But the prescription that the government use trade taxes to redistribute income may be inappropriate when the redistributive impact of trade taxes is likely to be regressive. ${ }^{11}$

An analysis of the appropriate policy for a particular country must therefore begin by specifying the reasons for market failure and the instruments the government can use to remedy it. The role of general theories is to identify the circumstances under which one kind of policy is more likely to be appropriate, thereby developing a taxonomy for analyzing policies in different countries. ${ }^{12}$ The models for specific countries help to frame the policy discussion. They enable one to establish whether the source of disagreement over policy is differences in objectives (welfare weights associated with different groups or between current generations and future generations); or differences in views about the structure of the economy; or differences in views about the values of key parameters (see Atkinson and Stiglitz 1980).

The following sections organize the evaluation of alternative policies around several themes: risk, incentives, credit, redistribution, dynamic effects, food subsidies, and considerations of political economy.

Most economists acknowledge that farmers face significant risks and have only limited opportunity to avoid them through insurance and other markets. However, appropriate remedies are the subject of theoretical and practical disagreement. ${ }^{13}$

What is of crucial importance to farmers is stabilizing their income, not stabilizing the prices of their produce. If price and quantity are negatively correlated, stabilizing prices may actually exacerbate the fluctuations in income.

Some economists favor the use of futures markets. These have the 
advantage of allowing a farmer to choose how much of his crop to sell forward, to "adapt" the extent of price stabilization to his own circumstances and preferences. But futures markets have two important drawbacks. First, they involve bigger transactions costs than those price stabilization schemes that work through the market. To the extent that such schemes serve to stabilize incomes, they do so without any farmer taking special action for himself. Second, to the extent that crop sizes are uncertain, no farmer can completely hedge his position unless he purchases crop insurance (which in general is unavailable). These disadvantages are not necessarily as bad as those produced by schemes in which the government does not stabilize the market price, but makes separate agreements with different farmers to buy given amounts of a crop at a guaranteed price.

Despite their transactions costs, futures markets dominate most types of price stabilization schemes. The intuitive reason is that futures markets allow the farmer to choose how much he wishes to divest himself of price risk. ${ }^{14}$ However, even in developed countries in which futures markets exist, farmers have not (at least until recently) used these markets to any significant extent. ${ }^{15}$ Thus, it remains an open question whether futures markets could be an effective way of sparing small farmers from risks.

If governments decide to stabilize prices, they have several ways to do so. They can, for instance, use buffer stocks, which can be operated according to various rules. Perfect price stability is, in essence, impossible. Even simple rules, such as setting a band within which prices can move, are not immune to speculative attack. ${ }^{16}$ The only generally feasible rules involve prices being a function of the size of the current stock; as the amount in storage decreases, the government allows the price to rise.

The limited calculations done so far suggest that the welfare gains from well-designed rules may be significantly greater than those from certain simple rules, such as keeping prices within a band (even if that were possible). ${ }^{17}$ Indeed, questions may be raised about the significance of the latter gains altogether (Newbery and Stiglitz 1982). As for buffer stocks, a major criticism is that it is usually more efficient to store general purchasing power than specific commodities-that is, to use savings and reserves-except when transport and transactions costs are large.

Another way for governments to try to affect price variability is to impose trade restrictions. These may have marked transactional advantages over other forms of price stabilization, though they may be less effective in stabilizing incomes. It is now widely recognized that, in the presence of uncertainty (and with limited governmental ability to respond to changing circumstances), quotas and tariffs are not interchangeable. Tariffs do not insulate a country from foreign- 
induced price fluctuations, but quotas may do so. Quotas are particularly effective when the source of price fluctuations is neither domestic demand nor supply; they can then completely insulate the producers from foreign shocks (at the cost, of course, of preventing a country from taking full advantage of its current comparative advantage). Quotas are also effective in the extreme case in which the only source of variability is domestic output; they then serve to raise prices whenever farmers are suffering from lower volume. Even in these circumstances, however, it is not clear that the gains from reducing risk exceed the costs of failing to take advantage of temporary comparative advantage. The calculations depend partly on supply responses.

With any price stabilization scheme, supply responses are a major uncertainty. How do farmers react to a reduction in risk? And to what extent do a government's price stabilization programs serve simply to replace the stabilizing (arbitrage) activities of the private sector? Little empirical work has been done on either of these issues, though the effects can clearly be large: some countries have had to restrict their farmers' production so as to limit the costs of government programs.

Though there often is a role for government intervention to reduce the risks faced by farmers, many of the programs justified on these grounds serve more to redistribute income than to stabilize it. Indeed, in some instances, they may actually increase the variability of income. The appeal of these programs may lie in the way that they conceal the size and allocation of subsidies. Were the subsidies provided more openly, they might not be politically acceptable. ${ }^{18}$

The taxes and subsidies in agriculture inevitably influence the behavior of farmers. They affect decisions to be a farmer and to allocate effort and other resources to agriculture. The most common form of influence occurs when governments try to tax agriculture- by taxing farm output directly or, equivalently, by setting up state marketing boards that purchase crops at less than the international price, by taxing export, or by putting tariffs on industrial goods. ${ }^{19}$ Lowering the price of farm products obviously reduces the incentives for farmers. Though the supply curve may bend backward in certain circumstances, in general supply will be reduced when taxes get sufficiently high. ${ }^{20}$ The welfare losses associated with such taxes may be particularly large in sharecropping economies, where the farmer receives between a third and two-thirds of the value of his marginal product. ${ }^{21}$

Economists concerned with incentives favor land taxes over output taxes, since the former are close to the economists' ideal: lump-sum taxes. The central problem, however, seems to be valuing the land. If each acre of land is taxed the same, irrespective of its quality, the tax 
would be thought unfair. But if the quality of land is judged on the basis of output, then a land tax is virtually the same as an output tax. In many developing countries, land markets are so thin that market price cannot be used; even in developed countries, there is considerable uncertainty about the true value of different properties.

In many countries, governments have tried to mitigate the effects of output taxes by combining them with input subsidies-particularly for fertilizer, seeds, and credit. If all inputs were subsidized to the same extent, such schemes would be equivalent to reducing the output tax. The same results could be achieved with lower transaction costs by cutting the output tax directly. In fact, however, subsidies are never the same for all inputs, if only because some key inputs are unobservable. The schemes therefore cause distortions, boosting the use of subsidized inputs relative to unsubsidized items.

According to the modern theory of the second best, the presence of a distortion does not mean that the subsidy policy is automatically bad; after all, the output tax itself induces distortions. But it is reasonable to suspect that, for raising a given revenue, the combination of taxing and subsidizing is not only transactionally inefficient, but also more distortive than a policy of imposing taxes on outputs and inputs. In other words, the input subsidy not only distorts the input choice, but (because it uses revenue) also requires an even higher tax on output than would otherwise be needed. Recent studies have confirmed this intuition; only under restrictive conditions is it desirable to subsidize inputs and tax output. ${ }^{22}$ In a sharecropping economy there are some circumstances in which a fertilizer subsidy might be desirable: for instance, the increased use of fertilizer could so raise the marginal product of labor that workers are induced to work harder, even though the price they receive for their output is lower. Under those conditions, of course, it would have paid the landlord to subsidize the fertilizer himself; no government subsidy is required (Braverman and Stiglitz 1986).

The same analysis applies in the choice between input subsidies and price supports as a way of encouraging production. Input subsidies introduce an inefficiency in the choice of technique, a distortion that can be avoided by using price supports. ${ }^{23}$ (Two further arguments for input subsidies-that they have desirable distributional consequences and beneficial dynamic effects-are discussed later in this article.)

Most developing countries produce several different crops. This raises the question of whether all crops should be subject to a uniform tax and, if taxes vary, which crops should be taxed at higher rates. The question involves both incentive and efficiency considerations. This section discusses only the former, because we have already noted that the key factor in determining the efficiency effects of taxes is the elasticity of supply. This may well differ across crops, suggesting that 
the loss in efficiency from taxing inelastically supplied crops may be less than from taxing those with high elasticity. ${ }^{24}$

One significant set of incentive issues concerns the attractions for rural dwellers of migrating to towns and cities; such migration often gives rise to urban unemployment. Migration naturally responds to differences in real incomes between the two sectors. ${ }^{25}$ Thus, an increase in the (relative) tax burden on farming may generate a further dead weight loss in extra urban unemployment. The importance of this obviously depends on the supply elasticity of migration, and on the extent of (marginally induced) urban unemployment, which in turn will depend on the degree of wage flexibility in urban areas. In some circumstances, these considerations should play a central role in policymaking.

It is a common observation that farmers in developing countries are unable to obtain credit, or that they can do so only at usurious interest rates. ${ }^{26}$ This is not, in itself, evidence of a market failure. Interest rates will be high if the probability of default is high-which is indeed often the case. At the same time, the fact that there is imperfect information on the credit risks of different individuals (the adverse selection problem) and on the actions of those individuals (the moral hazard problem) means that the market equilibrium is not, in general, (constrained) Pareto efficient. ${ }^{27}$

Nonetheless, government policies to boost credit for farmers need to take account of these adverse selection and moral hazard problems. The government is usually in no better (indeed, often worse) position for gathering information on the varying probabilities of default. Furthermore, a government credit program that involves some discretion in the granting of loans also contains scope for giving subsidies to particular individuals: whenever a "high-risk" farmer is granted a loan for which the interest rate has not been increased accordingly, he is obtaining an implicit subsidy. It is naturally difficult for an outsider to judge whether a subsidy has been granted; precisely for this reason, such programs are open to abuse. ${ }^{28}$

In spite of the difficulties of designing rural credit schemes, a few have been successful. ${ }^{29}$ Distilling the lessons of these successes (and the lessons from the many more numerous failures) remains a challenge for researchers.

In developed countries, there is a strong presumption in favor of tackling distribution issues through taxing income rather than commodities. ${ }^{30}$ This presumption is less strong in developing countries, precisely because of the limited range of redistributive instruments 
available to the government. If the government wishes to redistribute income to urban dwellers, the most effective way may be a commodity tax. Since in most developing countries people in rural areas are already worse off than their urban counterparts, such policies are regressive (see Lipton 1971). This suggests that policies which are notionally justified on distributional grounds may have other (for example, political) motivations. This in turn should make one suspicious of differential taxation: differential tax rates can be used to redistribute income not only from rich to poor, but also from poor to rich, from the politically powerless to the politically powerful, from one region to another.

The structure of agricultural prices not only affects the welfare of the rural areas relative to the urban, but also has distributional effects within the countryside. These latter effects are often used to justify taxing one commodity at a lower rate than others (because it is grown mostly by poorer farmers) or subsidizing one input (because it is used mostly by poorer farmers). An assessment of the distributional consequences of such policies needs to consider not only the direct effects, but also the indirect ones-in particular, the effects on the wages paid to landless laborers. Thus, if fertilizer decreases the marginal product of labor (at any level of input of labor), a subsidy on fertilizer might reduce the demand for labor and consequently the landless laborers' wage, in which case the distributional consequences will be regressive.

Ascertaining these "general equilibrium" consequences is seldom straightforward. Moreover, one has to be cautious about using, say, differential input subsidies to achieve certain distributional goals. Wealthier farmers are likely to use more of all inputs, including more fertilizer-so a fertilizer subsidy is likely to benefit them most. ${ }^{31}$ Indeed, in the central case of constant returns to scale, outputs and inputs will be precisely proportional.

In some cases, there may be systematic differences in input-output ratios according to different levels of wealth, because poorer farmers have different qualities of land or because they face different factor prices (or similarly, because rental markets are imperfect, so that the cost per day of using, say, a tractor is greater for them than for richer farmers). ${ }^{32}$

Whenever there are systematic differences in input-output ratios, it is possible to redistribute income through a combination of taxes and subsidies. But if the differences are small, of course, taxes and subsidies have to be large to attain even a limited amount of redistribution-and the associated distortions will also be large. In many cases, the amount of redistribution achieved probably cannot justify the distortions caused by policies that simultaneously tax output and subsidize inputs or subsidize some inputs and tax others. 
A rather different justification for subsidizing inputs has to do with the adoption of new technologies. If peasants were perfectly rational and risk markets were perfect, then farmers would adopt the new Effects technology if it increased their expected utility. No government subsidy would be needed.

Reality is different: risk markets are imperfect, and peasants are risk averse. Moreover, technologies that are riskier, but offer higher returns, yield more tax revenue for the government. Thus, the government has a real interest in encouraging the adoption of such technologies. If such technologies use a lot of fertilizer, for example, then a fertilizer subsidy may be an effective way of encouraging the adoption of the riskier technologies.

There is an added (and rather distinct) justification for governments to encourage the use of new technologies: when one farmer tries a new technology, he conveys a large amount of information to his neighbors. The presence of these informational externalities implies that farmers will have insufficient incentives for trying new technologies; the solution is to levy corrective (Pigovian) taxes or to provide subsidies.

The conflict between these dynamic efficiency objectives and distributional considerations raises a familiar problem. The farmers that are least risk averse are likely to be the large ones, so they are likely to be willing to try the new technology. ${ }^{33}$ Thus, subsidies for those who introduce the new technology are likely to be regressive. (The effect may be exacerbated if the new technologies are also capital intensive, and the larger farmers have easier access to capital markets or can borrow at lower interest rates.)

The issues of pricing food in towns and cities are linked to agricultural pricing policies in several ways. First, the prices received by farmers and those paid by consumers will sometimes have to be the same; the government is unable to prevent the black markets that result when it tries to put a wedge between the two sets of prices. In that case, policies which make farmers better off (by increasing the prices they receive) simultaneously make those in the urban areas worse off. Whether these effects on urban dwellers can, or will, be offset depends on how their wages are determined. ${ }^{34}$

Second, urban food subsidies are expensive: they increase the amount of revenue that the government must raise from other sources, including taxes imposed on farmers (or, alternatively, they reduce what the government can spend on investment and other programs).

Third, in closed economies, there is a "material balance" condition: 
if farmers produce less (because of a tax on their output), then-for demand to equal supply - urban prices must rise. Workers in the urban areas will thus be worse off, unless wages adjust.

Both efficiency and distributional issues arise in the analysis of the structure of taxes and subsidies in urban areas. Efficiency discussions focus on the dead weight loss associated with any tax or subsidy structure. However, it may be misleading to try to borrow from the findings of optimal tax theory, as it has been conceived in developed countries. Central to that theory is the assumption that the economy is at full employment and that taxation distorts the supply of labor. (If the labor supply was, for instance, inelastic, then uniform taxation would be desirable.) As urban unemployment is a serious problem in many developing countries, it is implausible that governments will be much concerned about any slight reduction in the supply of labor.

Moreover, under a variety of hypotheses, it seems reasonable to assume that wages will respond to changes in prices. This will be so if, for instance, workers' productivity depends on the wages they receive and the prices they pay, and firms set their wages to minimize their labor costs (per efficiency unit). In that case, if efficiency depends simply on the level of a worker's utility, uniform taxation is again desirable. But if efficiency is particularly sensitive to food prices (because efficiency depends on nutrition), then it may indeed be desirable to subsidize food. This analysis will obviously vary according to the nature of the job. If workers in urban areas are mainly employed in civil service jobs, where limited physical exertion is needed, the case for food subsidies may be weaker than in more industrialized urban settings.

The distributional effects of urban pricing policies are also likely to depend critically on how far food subsidies can be disaggregated. Thus, a uniform food subsidy is likely to have a smaller redistributive impact than a subsidy limited to millet, while in some countries, a subsidy just for rice may be regressive in its effects. If the government is particularly concerned with the poor yet cannot reach them directly, it may be desirable to have general food subsidies - even though the rich benefit more than the poor.

Considerations of Political Economy
Some of the issues discussed in this article have been a source of controversy for centuries. Governments have the power, through taxation, to redistribute income from one group to another, from one region to another. They have often used this power to favor urban dwellers over farmers, though in developed countries the pattern has recently been reversed. These redistributive objectives (which often seem only by coincidence to have much to do with egalitarianism) are pursued quite independently of their allocative effects. It is precisely 
these "distortionary" consequences of government intervention that have incurred the economists' wrath. Though it is true that the redistributive objectives might not be obtainable in a nondistortionary form, that does not detract from the central questions: how much redistribution, at what cost, and to whose benefit? ${ }^{35}$

No policy is ever perfect. Even if it were perfectly adapted to the circumstances that prompted it, circumstances change-and then there may be alternative policies that are more effective. The question of how to handle policy changes has recently been the subject of debate.

Should, for instance, the government make many small changes or a few large changes? The first option (sometimes referred to as policy "reforms") has the advantage that it requires only knowledge of demand and supply elasticities and cross elasticities (or other variables) in the current equilibrium. Deciding what large changes are desirable requires a wider knowledge of the structure of the economy-information that is seldom available (indeed, there is some question whether, without experiments, such information is obtainable at all). ${ }^{36}$ Nonetheless, there are significant (fixed) costs involved in making any change in policy, plus the costs of uncertainty whenever policy is changed frequently. ${ }^{37}$ There may also be significant distributive consequences from policy changes that may, at best, be capricious; for example, changes in the relative taxes of different agricultural goods will change relative land values; these taxes may be borne mainly by those who happen to own the land at the time the tax is announced.

Of course, the most significant transactional costs are the set-up costs involved in a particular tax or subsidy. Though simple models that ignore these costs might suggest that it is desirable to have, say, a small tax or subsidy on fertilizer, the administrative costs of setting up such a scheme may be largely independent of the size of the tax or subsidy; when these costs are taken into account, they show that a tax or subsidy should be applied only if it is large. Many of the major policy issues cannot really be considered within a framework that is limited to marginal changes in tax rates.

This article has stressed that the design of agricultural policies should be viewed as an exercise in the theory of second best, an exercise requiring detailed information about a country and careful Remarks judgment about the nature and relative importance of market (and nonmarket) failures.

Against these standards, most of the simplistic prescriptions fail. 
The assertion that governments should never intervene in agricultural markets misses the potential importance, in some cases, of market failures. Arguments against distortionary trade taxes often fail to recognize that revenue has to be raised somehow; that many governments do not have any nondistortionary methods of raising revenue; and that trade taxes may have distinct transactional merits. These points apply even against more recent arguments that the government should not impose trade taxes (Diamond and Mirrlees 1971).

Simple prescriptions have one obvious advantage: they enable economists to make policy judgments with virtually no knowledge of the country in question. But the flaws in the simplistic approach make it all the more important to accumulate detailed information on most of the developing world. The first step in any systematic analysis of agriculture policies is therefore to describe as accurately as possible the consequences of each policy. This requires a model of the economy concerned - and a model appropriate for one country may not be for another. Recent work has clarified some of the essential ingredients of these models: wage-setting policies in the urban sector, the nature of rural-urban migration, and the organization of the rural sector-labor, land, and credit markets. This descriptive and empirical work is essential before it is possible to make useful normative judgments that attach welfare weights to the effects of policies on various groups. ${ }^{38}$ Much of the recent work in optimal tax theory can be criticized on the grounds that it fails to make explicit the consequences of policy for various groups, providing only a summary description of the policy that maximizes some social welfare function. ${ }^{39}$

The weakness of simple prescriptions should not drive people to the opposite extreme of arguing that, in a second-best world, "anything is possible." Important qualitative statements can be made on the basis of certain qualitative information about the economy. This article has given one example of this tenet in developing countries: the simultaneous imposition of input subsidies and output taxes can be shown to be undesirable under certain conditions.

In any analysis of agricultural policies, the hardest part is to incorporate political economy considerations-to decide what are to be taken as political constraints. Again, though general answers may be impossible, some assumptions seem more reasonable than others. Thus, many analyses begin with the presumption that the government cannot lower the urban wage, but they also assume that the wage will not adjust in response to price increases. They assume, in other words, a kind of myopia, which may be valid in the short run, but seems implausible in the long run. It suggests more naiveté on the part of the economic theorist than is possessed by workers in developing countries.

Economists are also concerned about how their advice will be used. 
There is a large gap between the rationale for certain policies and their actual consequences; policies that are justified as redistributive, though they do indeed redistribute income, may do so in a regressive manner. This article has expressed particular doubts about policies involving differential taxation, which hide official subsidies and give the government discretion in the way they are allocated. The validity of these doubts may differ from country to country. But they matter less to the extent that economists concentrate on a positive description of the consequences of alternative policies.

In virtually every country, governments intervene in agricultural markets in a variety of ways-with subsidies and taxes, with credit, with price stabilization programs, and with expenditure programs. This article provides a systematic framework within which these various programs can be assessed. The analysis of any policy must begin with a description of its effects. An evaluation of the appropriateness of any policy must begin by specifying the reasons for market failure and the instruments at the disposal of the government. The article focuses on the consequences of imperfect risk and credit markets and considers the incentive and distributive effects of alternative government programs.

1. See, for instance, Binswanger and Scandizzo (1983).

2. This article is not a systematic review of the relevant literature; rather, its objective is to develop a perspective within which to view government policies toward agriculture. Bibliographical references have, accordingly, been kept to a minimum. This article elaborates on another recent survey (Johnson 1986). Johnson argues that "governmental intervention in agricultural markets should occur only when there is a strong affirmative case for so doing" (p. 15). The present article considers the conditions under which this will be true and the consequences of alternative policies under those circumstances.

3. The following list of market failures is neither exhaustive nor mutually exclusive. For instance, as noted below, problems of imperfect information provide part of the explanation for incomplete risk and credit markets.

4. Insurance markets are notoriously bad in many contexts other than agricultural markets. Particular problems in agricultural markets are adverse selection and moral hazard: the farmer is likely to be better informed about the hazards he faces than the insurer (this is referred to as the adverse selection problem); and there are actions the farmer can take that affect output (or, more generally, the insurance companies' expected liability; this is referred to as the moral hazard problem). Thus, though the farmer cannot affect whether there is a hailstorm, he can affect the losses he incurs if one happens, by taking precautionary action. Adverse selection and moral hazard problems need to be taken into account in the design of insurance contracts.

Government policies that ignore adverse selection and moral hazard may exacerbate the problems. Thus, government stabilization programs may induce farmers to increase their production of risky crops, thus imposing a greater cost on government than it would otherwise have to face.

5. Most economists, believing in consumer sovereignty and individualistic social welfare functions, are more concerned about their low income than a low consumption of particular commodities, such as food or health services. There is, however, no unanimity on this point. Tobin (1970) for instance, has put forward the notion of "specific equalitarianism," arguing that society should be concerned with the levels of consumption of particular commodities. 
6. What often seems of concern is not only the level of income but changes in income. If, for example, technological change makes many small farms economically unviable, government policies may be aimed at easing the transition of these small farmers out of agriculture. These programs may be thought of as a response to the market's failure to provide insurance against such changes.

7. A pure insurance or price stabilization program would, of course, just break even, with losses when prices are low offset by profits when prices are high.

8. See Braverman and Guasch (1986) for a review of the empirical findings on the impact of rural credit programs.

9. Indeed, the problems associated with distinguishing between good and bad borrowers and of monitoring the actions of borrowers enhance the scope for political abuse within subsidized credit schemes.

10. Most developing countries do not have the administrative wherewithal for an effective and equitable income tax system. Moreover, in economies in which private bookkeeping procedures are limited, the marginal social cost for implementing an income tax system may be unduly high.

11. Economists naturally feel (and should feel) less confident about statements concerning how their advice might be used or abused. Some economists claim that their responsibility is limited to explaining what taxes attain what distributive goals most efficiently. But political processes are no less real than economic processes, even if they are less understood. The question can be put in a more analytical way. Assume we believed that the political process was well described by a majority voting model. Because the future is uncertain, it is obviously undesirable to specify precise tax rates. Economists are asked whether there should be a constitutional restriction to uniform taxation of commodities. An economist brought up on the Ramsey rules might be tempted to say no. But an economist brought up in the social choice tradition would ask, if we have majority voting, what kinds of differential tax rates are likely to be imposed? Under some circumstances, that economist might conclude that expected social welfare would be higher, given the political process, under a constitutional restriction to uniform taxation.

12. All modeling requires simplification. Thus, the fact that a model leaves out certain aspects of reality is not in itself a criticism. It is, of course, essential that what is left out is of secondary importance. Many of the debates about the appropriateness of different theories turn on disagreements about the significance of some feature of the economy, which has been omitted from one model but plays an important role in another.

13. For a more extensive discussion of the issues associated with risk in the context of developing countries, see Newbery and Stiglitz (1981).

14. With futures markets, farmers must decide (usually before the size of their crop is known) how much of their crop to sell forward; if their crop exceeds the amount sold forward, they bear a price risk on the difference. With price stabilization schemes, the price is stabilized on all of their output, regardless of its size.

15. Perhaps this is so because of the large transactions costs in these markets or because small farmers may feel that they are at an informational disadvantage relative to speculators or large trading companies (it is well known that markets with such asymmetric information are likely to be thin or nonexistent; see Akerlof 1970). They may also be concerned that such markets may be subjected to manipulation.

16. When, for instance, the price approaches its floor, speculators believe that the government will probably not be able to sustain the price, so they sell their stocks, making it indeed impossible for the government to maintain the floor (Salant 1979).

17. These calculations suggest that the value of social welfare is sensitive to the precise stabilization rule employed. This should be contrasted with calculations on, for instance, the optimal tax rate, where, under a variety of circumstances, it appears that the value of social welfare is not very sensitive to the tax rates imposed. 
18. In many developing countries, agricultural marketing boards, which are often justified in terms of their role in stabilizing prices, at the same time serve to tax agriculture.

19. It may not be obvious that industrial tariffs should really be viewed as a tax on agriculture. In a general equilibrium model, all that is relevant is relative prices. Increasing the price of industrial goods has the same effect as reducing the price of agricultural goods. This fact is, of course, eventually discovered by farmers and has been a source of strife in developed countries.

20. Even if supply curves do bend backward, with income effects and substitution effects offsetting each other, there are dead weight welfare losses.

21. Though the more theoretical work on sharecropping suggests that the shares ought to respond to these changes in circumstances, there is little evidence that they do so, perhaps for the reasons suggested by Allen (1985). It is important to note that the sharecropping system is not necessarily inefficient; that it may represent a reasonable response to the problems of incentives and risk in farming. (See Cheung 1969; Stiglitz 1974.) Nonetheless, with a positive labor supply elasticity, output under sharecropping may be much less than it would be after a land reform, in which land was redistributed to the peasants.

22. See Sah and Stiglitz (1985). These conditions entail large cross elasticities of demand, significant nonhomotheticity in the production function, and significant general equilibrium wage effects. Their analysis does not, however, apply to sharecropping.

23. This is a heuristic argument. The general theory of the second best has emphasized the inappropriateness of counting distortions. Diamond and Mirrlees (1971) have established a general theorem concerning the desirability of production efficiency. Though Dasgupta and Stiglitz (1971) have noted several important limitations to that theorem (in particular, the theorem requires that the government have a rich set of instruments at its disposal), it still seems that, in the case examined here, there is a presumption in favor of production efficiency.

24. Cross elasticities between the outputs of different crops must also be taken into account. The importance of these cross elasticities depends on how fine will be the differentiation among commodities. That is, the cross elasticity between two types of wheat is likely to be much greater than the cross elasticity between wheat and rice. Johnson (1986) has suggested that the differential taxes imposed on wheat relative to rice-which is significant in both China and India-may have more to do with the greater political influence of wheat farmers than rice farmers.

25. In some cases, reducing the price received by farmers might reduce migration. If farmers are credit constrained, then when they are worse off they may be less able to finance extended unemployment in urban areas. See Kanbur (1981).

26. For two recent surveys of the issues involved in rural credit, see Braverman and Guasch (1986) and Lipton (1981).

27. That is, they are not Pareto efficient, even taking into account the limitations in information; there exist government policies that could, in principle, make everyone better off.

28. Even the private sector has difficulty designing managerial incentive schemes to assess these risks. Whether a particular loan is "good" or not will often not be apparent for several years, after the loan officer has departed for another job.

29. Braverman and Guasch (1986) cite several such instances, including the INVIERNO Development Bank Program, implemented in Nicaragua in 1975, programs in Korea (see also Lee and others 1977), and Kenya's Cooperative Savings Scheme (von Pischke 1983).

30. In certain limiting cases, it can be shown that if there is an optimal (or Pareto efficient) tax structure, then no commodity taxes should be imposed. Even with an optimal linear tax, the presumption against commodity taxation remains fairly strong. More generally, the properties of the demand systems that determine whether commod- 
ity taxes should be imposed and, if so, at what rates are at best hard to estimate. Thus, for instance, with the frequently estimated linear expenditure system, it is always the case with an optimal linear income tax that no commodity taxation should be imposed, if the only source of inequality is differences in individuals' wages (including differences in wealth that result from these wage differences).

More generally, while the distortions arising from taxing commodities that are inelastically demanded may be small, those commodities generally have low income elasticities, so that taxing them has regressive distributional consequences. In many cases, once an optimal income tax is imposed, these distributional and incentive effects exactly balance each other, making it desirable to impose no commodity taxation at all.

31. Subsidy schemes in which the size of the subsidy depends on the income of the farmer may be used in some circumstances. The simplest schemes enable each farmer to buy a given amount of fertilizer at a subsidized price. For all farmers who buy more than that amount, the subsidy is equivalent to a lump sum subsidy (and in this sense, has nothing to do with fertilizer). If black markets cannot be prevented, even those who use less than the given amount will purchase the subsidized fertilizer for resale. Then the fertilizer subsidy does nothing more than provide a uniform lump sum for all individuals.

32. The cost differences associated with rental versus ownership markets may reflect important moral hazard problems. The fact that these differences are not a consequence of a "market failure" does not lessen the distributional consequences. A similar point applies to the different costs of capital facing different farmers.

In some cases, incentive and distributional considerations pull in opposite directions; in others, they reinforce each other. Assume, for instance, that because of lack of access to the capital market, poor farmers use less fertilizer. A fertilizer tax would then have a beneficial distributive effect. But, at the same time, the marginal product of fertilizer is much higher among the poor than among the rich. A fertilizer subsidy would partly offset the inefficiencies arising from the poor's lack of access to capital. In this case, although the poor consume less fertilizer, the increment in income resulting from a fertilizer subsidy may be larger.

33. Moreover, to the extent that there are fixed costs associated with acquiring information needed to implement a new technology, large farmers have a greater incentive to make the requisite expenditures. To the extent that these costs are borne by the government (through agricultural extension services), these effects are mitigated.

34. See Braverman and Kanbur (1986) for a model examining these questions in an African context.

35. Perhaps the question that should be posed is not, What is the optimal set of taxes and subsidies? Rather, the question is, Given the political processes that determine which taxes or subsidies will be chosen, what constraints should be imposed on the set of admissible taxes or subsidies? Some contend that the answer to this question, in many contexts, involves uniform taxation.

36. At issue is not the lack of econometric research or the unavailability of data. The economy may simply not have experienced, say, relative prices in the range in which some policy might take it. Though economists frequently assume constant elasticity functions, allowing them to project the consequences, this is little more than guess work; even if elasticities were approximately constant over the range of relative prices that have been experienced, there is no reason to believe that the elasticity would remain constant outside that range.

37. Although again, it is not apparent whether there is more effective uncertainty associated with a large number of small changes or infrequent large changes in policy.

38. Braverman and Hammer have emphasized in their work the importance of a careful positive description of the consequences of policy, incorporating the constraints and distortions within the country. See, for instance, Braverman and Hammer (1986); Braverman, Hammer, and Ayn (1986); and Braverman, Hammer, and Gron (1986). 
39. More recent work on Pareto efficient tax structures attempts to identify the characteristics of the tax structures that apply regardless of the normative judgments employed. For a review of this work, see Stiglitz (1987).

Akerlof, George. 1970. "The Market for 'Lemons': Qualitative Uncertainty and the Market Mechanism." Quarterly Journal of Economics 84: 488-500.

Allen, Franklin. 1985. "On the Fixed Nature of Sharecropping Contracts." Economic Journal (March): 30-48.

Atkinson, A. B., and Joseph E. Stiglitz. 1980. Lectures on Public Economics. New York: McGraw-Hill.

Binswanger, Hans P., and Pasquale L. Scandizzo. 1983. Patterns of Agricultural Protection. Agriculture Research Unit Discussion Paper 15. Washington, D.C.: World Bank, Agriculture and Rural Development Department.

Braverman, Avishay, and Luis Guasch. 1986. "Rural Credit Markets and Institutions in Developing Countries: Lessons for Policy Analysis from Practice and Modern Theory." World Development. Forthcoming.

Braverman, Avishay, and Ravi Kanbur. 1986. Urban Bias and the Political Economy of Agricultural Price Reform. AGREP Working Paper 117. Washington, D.C.: World Bank, Agriculture and Rural Development Department.

Braverman, Avishay, and Jeffrey S. Hammer. 1986. "Multimarket Analysis of Agricultural Pricing Policies in Senegal." In Inderjit Singh and others, eds. Agricultural Household Models: Extensions, Applications, and Policy. Baltimore, Md.: Johns Hopkins University Press.

Braverman, Avishay, Jeffrey S. Hammer, and C. Y. Ayn. 1986. "Multimarket Analysis of Agricultural Pricing Policies in Korea." In David Newbery and Nicholas Stern, eds. The Theory of Taxation in Developing Countries. New York: Oxford University Press. Forthcoming.

Braverman, Avishay, Jeffrey S. Hammer, and Anne Gron. 1986. "Multi-Market Analysis of Agricultural Price Policies in an Operational Context: The Case of Cyprus." World Bank Economic Review. Forthcoming.

Braverman, Avishay, and Joseph E. Stiglitz. 1986. "Cost Sharing Arrangements under Sharecropping: Moral Hazard, Incentive Flexibility, and Risk." Journal of the American Agricultural Association. Forthcoming.

Cheung, S. N. 1969. The Theory of Share Tenancy. Chicago: University of Chicago Press.

Dasgupta, Partha, and Joseph E. Stiglitz. 1971. "Differential Taxation, Public Goods, and Economic Efficiency." Review of Economic Studies 38: 151-74.

Diamond, Peter, and James Mirrlees. 1971. "Optimal Taxation and Public Production I: Production Efficiency." American Economic Review 61: 8-27.

Johnson, D. Gale. 1986. "Policy Issues in Rainfed Agriculture." Paper presented at the World Bank's Sixth Agricultural Symposium, Washington, D.C., January 10.

Kanbur, Ravi. 1981. "Short-Run Growth Effects in a Model of Costly Migration with Borrowing Constraints: Will Rural Development Work?" In D. Currie and others, eds. Essays in Microeconomics and Economic Development. London: Croom Helm.

Lee, D. H., and others. 1977. "Savings Deposits and Agricultural Cooperation in Korea." Asian Survey 17: 1182-94.

Lipton, Michael. 1971. Why Poor People Stay Poor: A Study in Urban Bias in World Development. London: Temple Smith.

. 1981. "Agricultural Finance and Rural Credit in Poor Countries." In Paul 
Streeten and Richard Jolly, eds. Recent Issues in World Development: A Collection of Survey Articles. Elmsford, N.Y.: Pergamon.

Newbery, David N., and Joseph E. Stiglitz. 1981. The Theory of Commodity Price Stabilization. London: Oxford University Press.

. 1982. "Optimal Stockpiling Rules." Oxford Economic Papers 34, no. 3 (November): 403-27.

Sah, Raaj, and Joseph E. Stiglitz. 1985. Taxation and Pricing of Agricultural and Industrial Goods in Developing Countries. Economic Growth Center Discussion Paper 475. New Haven, Conn.: Yale University.

Salant, Stephen. 1979. "The Vulnerability of Price Stabilization Programs to Speculative Attack." Journal of Public Economics 91, no. 1 (February): 1-38.

Stiglitz, Joseph E. 1974. "Incentives and Risk Sharing in Sharecropping." Review of Economic Studies (April): 219-55. 1986. The Economics of the Public Sector. New York: Norton.

. 1987. "Pareto Efficient and Optimal Taxation and the New New Welfare Economics." In Alan Auerbach and Martin Feldstein, eds. Handbook on Public Economics, vol. 2. Amsterdam: North-Holland. Forthcoming

Tobin, James. 1970. "On Limiting the Domain of Inequality." Journal of Law and Economics 13: 262-77.

von Pischke, J. D. 1983. “A Penny Saved: Kenya's Cooperative Savings Scheme.” In J. D. von Pischke and others, eds. Rural Financial Markets in Developing Countries. Baltimore, Md.: Johns Hopkins University Press. 